\title{
Foliar fertilizers for the management of phoma leaf spot on coffee seedlings
}

\author{
Manoel Batista da Silva Júnior ${ }^{1}$ | Edson A. Pozza ${ }^{1}$ | Mário L. V. Resende ${ }^{1}$ | \\ Pedro M. R. Júnior $^{2}$ | Bruno H. G. Costa ${ }^{1}$ | Camila A. Carvalho ${ }^{1}$ | \\ Alexandre R. M. Resende ${ }^{1}$ | Deila Magna dos Santos Botelho ${ }^{1}$
}

${ }^{1}$ Department of Plant Pathology, Federal University of Lavras, Lavras, Brazil

${ }^{2}$ Embrapa Semiarido, Petrolina, Brazil

Correspondence

Edson A. Pozza, Department of Plant Pathology, Federal University of Lavras, Lavras, Brazil.

Email: edsonpozza@dfp.ufla.com

\begin{abstract}
The growing demand for alternative strategies for plant disease management has sought a reduction in the use of fungicides via the employment of resistance inducers and foliar fertilizers, among others. Therefore, this study aimed at evaluating the following foliar fertilizers for the management of phoma leaf spot: a foliar fertilizer based on macro- and micronutrients (Fmm: 10\% N, 4\% S, B, 5\% Fe and 5\% Zn); one based on cobalt and molybdenum ( $\mathrm{Fcm}: 2 \% \mathrm{Co}$ and $3 \% \mathrm{Mo}$ ); manganese phosphite ( $F M n: 30 \% \mathrm{P}_{2} \mathrm{O}_{5}$ and $9 \% \mathrm{Mn}$ ); and the $\mathrm{FMn}+\mathrm{Fmm}, \mathrm{Fcm}+\mathrm{Fmm}$ and $\mathrm{FMn}+\mathrm{Fcm}+\mathrm{Fmm}$ associations compared to a boscalid fungicide and a control with no treatment. The disease severity, the chlorophyll $a$ and $b$ contents, the net photosynthetic rate (LPR), the phenylalanine ammonia lyase (PAL) activity and the lignin content in leaves were assessment. Based on the severity, the area under the disease severity progress curve (AUSPC) and the efficiency of disease control in relation to untreated plants were calculated. The experimental design was in randomized blocks with eight treatments and three replications. Treatments FMn+Fmm and Fcm were the most effective in reducing the AUPSC in comparison with the control and promoted an increased activity of PAL. FMn was the treatment that promoted the highest increase in the LPR. There were no effects of the treatments on the lignin content compared to the control.
\end{abstract}

KEYWORDS

alternative control, Coffea arabica, nutrients, Phoma tarda

\section{1 | INTRODUCTION}

Phoma leaf spot (Phoma tarda (R.W. Stewart) H. Verm.) is one of the major diseases in coffee plantations. Symptoms include leaf lesions, dry branches, rotted flowers and fruits with their subsequent falling, thus reducing crop yield (Pozza, Carvalho, \& Chalfoun, 2010). Disease is favoured by temperatures under $20^{\circ} \mathrm{C}$ and leaf wetness that is not necessarily caused by high-intensity rainfall (Santos et al., 2014). In such conditions, the crop losses caused by the disease may range from 15 to $43 \%$ (Nojosa, Resende, Barguil, Moraes, \& Vilas Boas, 2009).

The Brazilian Coffea arabica L. cultivars are susceptible to phoma leaf spot. Chemical control is performed periodically in areas prone to epidemics. However, consumers are increasingly demanding food with little or no residual fungicides (Aktar, Sengupta, \& Chowdhury, 2009). Thus, coffee farmers are currently seeking reduced pesticide options or management strategies against diseases increasing yield as well as reducing production costs. In this context, both the mineral 
nutrition and resistance induction are able to improve plant defence (Huber, 1980). These management strategies can decrease the rate of disease progress, contributing to a reduction of fungicide use.

The nutritional imbalance of macro- and micronutrients can increase the intensity of phoma leaf spot in coffee trees (Lima et al., 2010). Foliar sprays of fertilizers have been used to provide essential micronutrients for metabolic pathways necessary to reinforce resistance barriers against plant pathogens, such as the wax layer and the cell wall, in addition to acting as cofactors of several enzymes involved in defence responses, chlorophyll content and photosynthesis (Gong et al., 2011; Pozza \& Pozza, 2012; Taiz \& Zeiger, 2013). Therefore, foliar sprays of fertilizers have direct and indirect effects on the management of coffee diseases (Lichston \& Godoy, 2006). These micronutrients may also be supplied in association with resistance inducers such as phosphites, allowing both nutritional balance and resistance induction (Costa et al., 2017; Gadaga, Abreu, Resende, \& Ribeiro Júnior, 2017). Nojosa et al. (2009) observed a reduction of up to $80 \%$ in the severity of phoma leaf spot in coffee seedlings with the foliar pulverization of potassium phosphite, acibenzolar-S-methyl and a leaf fertilizer formulation consisting of boron, copper, sulphur, manganese and zinc. Costa et al. (2014) found a reduction of $72 \%$ in the area under the severity progress curve (AUSPC) of coffee rust with the foliar spraying of manganese phosphite. However, the evaluation of different formulations of micronutrients mixed with phosphites and their implication in the photosynthesis has not yet been studied.

The objectives of this research were to verify the effect of formulations of foliar fertilizers and phosphites on coffee seedlings for phoma leaf spot management and on the activity of phenylalanine ammonia-lyase (PAL), lignin content, chlorophyll $a$ and $b$ contents and photosynthesis.

\section{2 | MATERIAL AND METHODS}

Four trials were performed to investigate the effect of three formulations of foliar fertilizers on the protection against phoma leaf spot and net photosynthesis in coffee seedlings. All trials were replicated twice.

\section{1 | Inoculum and plant material obtention}

The fungus $P$. tarda was isolated from symptomatic coffee leaves collected in the plantations in the municipality of Santo Antônio do Amparo, State of Minas Gerais, Brazil, and transferred to Petri dishes containing $2 \%$ malt agar culture medium. After 15 days of incubation in biological oxygen demand (B.O.D.) at $20^{\circ} \mathrm{C}$ and a photoperiod of $12 \mathrm{hr}$ of light, colonies with conidia and mycelium were scraped, added to $200 \mathrm{ml}$ water agar $(0.2 \%)$ and crushed in a blender for $1 \mathrm{~min}$. The suspension was calibrated in a Neubauer chamber to adjust the concentration to $1 \times 10^{5}$ conidia.m/L.

The susceptible cultivar used in all trials was seven-month-old Mundo Novo 379/19 with six leaf pairs. The seeds were planted in $0.5 \mathrm{~L}$ plastic bags. Seedlings were maintained in a growth chamber, where trials were performed at $20 \pm 2{ }^{\circ} \mathrm{C}$ and $70 \%$ moisture for 15 days before carrying out the experiments.

\section{2 | Treatments}

Commercial formulations of foliar fertilizers based on macro- and micronutrients compared to a commercial fungicide and the control pulverized only with water were used; thus, there were a total of eight treatments (Table 1).
TABLE 1 Treatments used in trials to evaluate the effect of foliar fertilizers in coffee seedlings regarding the protection against phoma leaf spot, chlorophyll a and b contents and photosynthesis

\begin{tabular}{|c|c|c|}
\hline Treatments & Specification & Dosage \\
\hline 1.Control & - & - \\
\hline 2. Fungicida (boscalid) & Fungicide & $0.375 \mathrm{~g} / \mathrm{L}$ \\
\hline $\begin{array}{l}\text { 3. Foliar fertilizer based on macro- and } \\
\text { micronutrients }(10 \% \text { N, } 4 \% \text { S, B, } 5 \% \text { Fe and } \\
5 \% \mathrm{Zn})\end{array}$ & $\mathrm{Fmm}$ & $7.5 \mathrm{ml} / \mathrm{L}$ \\
\hline $\begin{array}{l}\text { 4. Foliar fertilizer based on cobalt and } \\
\text { molybdenum( } 2 \% \mathrm{Co} \text { and } 3 \% \mathrm{Mo})\end{array}$ & $\mathrm{Fcm}$ & $2.5 \mathrm{ml} / \mathrm{L}$ \\
\hline $\begin{array}{l}\text { 5. Manganese phosphite }\left(30 \% \mathrm{P}_{2} \mathrm{O}_{5} \text { and } 9 \%\right. \\
\mathrm{Mn})\end{array}$ & FMn & $3.5 \mathrm{ml} / \mathrm{L}$ \\
\hline $\begin{array}{l}\text { 6. Manganese phosphite }+ \text { Foliar } \\
\text { fertilizer based on macro- and } \\
\text { micronutrients }\end{array}$ & $\begin{array}{l}\mathrm{FMn}+ \\
\mathrm{Fmm}\end{array}$ & $\begin{array}{l}3.5 \mathrm{ml} / \mathrm{L} \\
7.5 \mathrm{ml} / \mathrm{L}\end{array}$ \\
\hline $\begin{array}{l}\text { 7. Foliar fertilizer based on cobalt and } \\
\text { molybdenum + Foliar fertilizer based on } \\
\text { macro- and micronutrients }\end{array}$ & $\begin{array}{l}\mathrm{Fcm}+ \\
\mathrm{Fmm}\end{array}$ & $\begin{array}{l}2.5 \mathrm{ml} / \mathrm{L} \\
7.5 \mathrm{ml} / \mathrm{L}\end{array}$ \\
\hline $\begin{array}{l}\text { 8. Manganese phosphite+ Foliar fertilizer } \\
\text { based on cobalt and molybdenum + Foliar } \\
\text { fertilizer based on macro- and } \\
\text { micronutrients }\end{array}$ & $\begin{array}{l}\mathrm{FMn}+ \\
\mathrm{Fcm}+ \\
\mathrm{Fmm}\end{array}$ & $\begin{array}{l}3.5 \mathrm{ml} / \mathrm{L} \\
2.5 \mathrm{ml} / \mathrm{L} \\
7.5 \mathrm{ml} / \mathrm{L}\end{array}$ \\
\hline
\end{tabular}

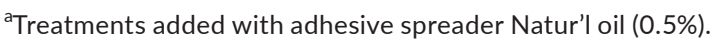




\section{3 | Foliar fertilizers for the protection of coffee seedlings to phoma leaf spot}

To investigate the effect of foliar fertilizers on the protection of coffee seedlings against phoma leaf spot, the treatments (Table 1 ) were sprayed on the leaves of seedlings. The experimental design was in randomized blocks with two plants per experimental unit and three replications.

Fertilizer application was carried out using a hand sprayer up to the dripping point on both sides of the leaves. P. tarda was inoculated 7 days after the spraying treatments (Nojosa et al., 2009). Then, inoculated plants were kept in a moist chamber for 5 days, with the aid of plastic bags, where seedlings were acclimatized at $20 \pm 2^{\circ} \mathrm{C}$.

After the onset of symptoms, five severity assessments of phoma leaf spot were carried out at seven-day intervals. Five pairs of leaves were evaluated in each of the two plants in the replication, making a total of 20 leaves per plot. The severity was determined by diagrammatic scale (Salgado, Pozza, Lima, Pereira, \& Pfenning, 2009). Disease progress curves were plotted. The area under the disease severity progress curve (AUSPC) was calculated according to Shaner and Finney (1977). Using the AUSPC data, the efficiency of disease control in relation to untreated plants was obtained.

\subsection{Chlorophyll $a$ and $b$ contents and net photosynthetic rate in coffee seedlings}

This trial was conducted in a randomized block design with three replications and two plants per replication with the treatments described in Table 1. The chlorophyll a and b contents and the liquid photosynthetic rate were then calculated. Five evaluations of the chlorophyll $\mathrm{a}$ and $\mathrm{b}$ contents were determined in four leaves from the middle third of the plants (8 plants per plot). The first evaluation was performed before the treatments. Thus, four readings per leaf were carried out using a portable chlorophyll meter SPAD-502 ${ }^{\circledR}$ (Soil Plant Analysis Development). Afterwards, a standard curve for chlorophyll was made according to Arnon (1949) using coffee leaves with different shades of green (from yellowish leaves to dark-greenish leaves) to correlate the colour of leaves with the chlorophyll meter readings. The chlorophyll concentrations were calculated with the Whitham, Blaydes, and Devlin (1971) formulas:

Chlorophyll $\mathrm{a}=\left(\left(12,7 \times \mathrm{A}_{663}-2,69 \times \mathrm{A}_{645}\right) \mathrm{V} 1000 \mathrm{MF}\right)$ and

Chlorophyll $b=\left(\left(22,9 \times A_{645}-4,68 \times A_{663}\right) \vee 1000 M F\right)$, where $A$ is the absorbance, $\mathrm{V}$ is the final volume of extract $(10 \mathrm{ml})$ and $M F$ is the weight of the fresh plant in grams.

The chlorophyll production curves were plotted against these data. From the chlorophyll content, the areas under the progress curve of chlorophyll A (AUACPC) and B (AUBCPC) were measured according to Shaner and Finney (1977). The percentage of efficacy of each treatment in comparison to the control to Abbott (1925) was also measured.

The liquid photosynthetic rate was measured using the infrared gas analyser (IRGA) LI-6400XT Portable Photosynthesis System, LI-COR ${ }^{\circledR}$ (Lincoln, USA), in fully expanded leaves at the third or fourth pair of leaves 28 days following the spraying treatment. Readings were performed at approximately 9 and 10 hours in the morning using an artificial source of photosynthetically active radiation (PAR) in a closed chamber adjusted at $1,000 \mu \mathrm{mol}$ photons $\mathrm{m}^{-2} \mathrm{~s}^{-1}$ (Blue + Red LED LI-6400-02B, LI-COR, Lincoln, USA).

\section{5 | Phenylalanine ammonia-lyase (PAL) activity and lignin content in coffee seedlings}

The activity of phenylalanine ammonia-lyase (PAL) and the lignin content were evaluated with the previously described treatments.

To analyse PAL activity, all treatments were inoculated, and then, four fully expanded leaves in the middle third were collected from each plant at 24, 48, 96 and $192 \mathrm{hr}$ following the application of the treatments (Silva et al., 2014). To evaluate the lignin content, leaves were collected at $192 \mathrm{hr}$ following the application. The experiment was performed in a completely randomized design with three replications and 8 plants per replication.

Collected leaves were packed in aluminium foil, frozen in liquid nitrogen and subsequently stored in a freezer at $-80^{\circ} \mathrm{C}$ until further analyses. To obtain the enzymatic extract and determine the PAL activity, samples of leaf tissue weighing $1 \mathrm{~g}$ were macerated in liquid nitrogen in a mortar with $1 \%(\mathrm{p} / \mathrm{v})$ polyvinylpyrrolidone (PVP) until the tissue became a fine powder. The powder was homogenized in $2 \mathrm{ml}$ $100 \mathrm{mM}$ potassium phosphate buffer ( $\mathrm{pH}$ 7.0). The homogenate was centrifuged at $14,000 \times \mathrm{g}$ for $25 \mathrm{~min}$ at $4^{\circ} \mathrm{C}$. The supernatant was used to determine the PAL activity (Zucher, 1965). The absorbance derived from the trans-cinnamic acid was measured at $290 \mathrm{~nm}$, and a molar extinction coefficient $10^{4} \mathrm{mM}^{-1} \mathrm{~cm}^{-1}$ was used to calculate the activity of PAL, which was expressed in $\mu \mathrm{M} \mathrm{min}{ }^{-1} \mathrm{mg}^{-1}$ protein. The total protein content was quantified in the same extract, according to Bradford (1976).

To determine the total soluble lignin content, leaves were crushed in liquid nitrogen until they became a fine powder and then were lyophilized for $24 \mathrm{hr}$. An aliquot of $30 \mathrm{mg}$ of this material was used to determine the lignin content using the thioglycolic acid method (Rodrigues, Jurick, Danoff, Jones, \& Rollins, 2005).

\section{6 | Statistical analyses}

To verify the assumptions of the analyses of variance, data of all variables were subjected to the Shapiro-Wilk test. The variables significant in the F test were subjected to the Scott-Knott test at 5\% probability using the statistical software R 3.1.3.

\section{3 | RESULTS}

\section{1 | Foliar fertilizers for the protection of coffee seedlings against phoma leaf spot}

A higher severity of phoma leaf spot $(25 \%)$ was found at the $35^{\text {th }}$ days after inoculation (DAI), while for the fungicide, the maximum 

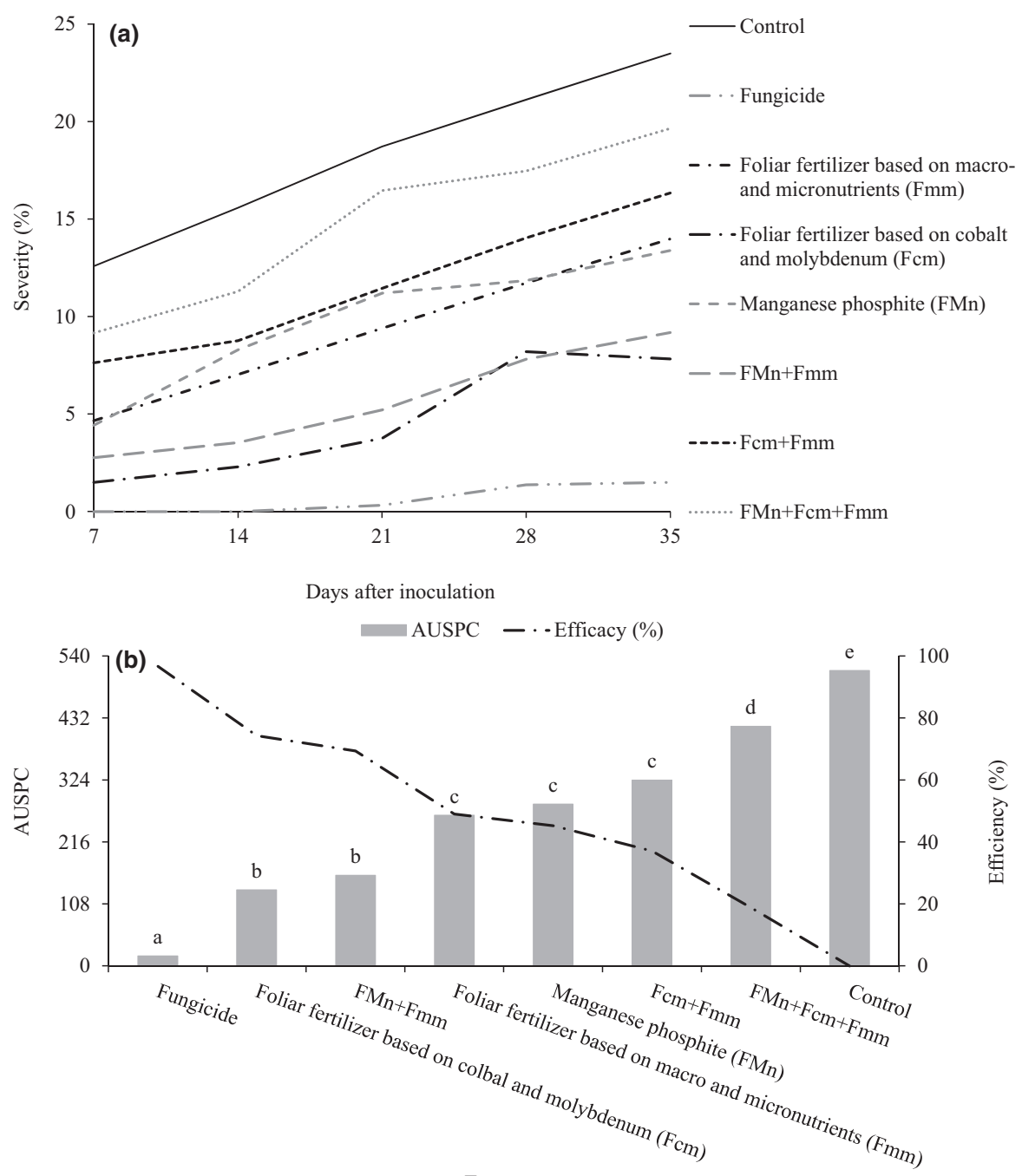

FIGURE 1 Effect of the treatment on: the progress of the severity $(A)$, area under the disease severity progress curve (AUSPC) (B) of phoma leaf spot in coffee seedlings cultivar Mundo Novo and the percentage of control (\%) provided by the treatments. Bars with the same letter do not differ according to Scott-Knott $(p \leq 0.05)$

Treatments

The net photosynthetic rate (LPR) was higher for all treatments in relation to the controls. FMn and the fungicide were improved compared to the other treatments and provided increased LPR from 138 to $215 \%$, respectively, while the other treatments exhibited an intermediate behaviour differing from the controls, with increased LPR ranging from $138 \%$ to $215 \%$ (Figure 3).

\section{3 | Phenylalanine ammonia-lyase activity and lignin content in coffee seedlings}

$\mathrm{Fcm}+\mathrm{Fmm}$ and $\mathrm{FMn}+\mathrm{Fcm}+\mathrm{Fmm}$ differed from the control regarding lignin content and provided increases of 22 and 36\%, respectively. The other treatments did not differ from the control (Figure 4A). Phenylalanine ammonia-lyase (PAL) reached peak activity at 96 hours following treatment application. FMn+Fmm and Fcm treatments provided broader activity peaks in PAL activity when compared to the control with stable activity throughout the assessments, while Fcm+Fmm had a progressive increase in activity, with a final peak at $192 \mathrm{hr}$ (Figure 4). 
(a)

Control

-----Fungicide

......... Foliar fertilizer based on macro - and micronutrients ( $\mathrm{Fmm})$

- - Foliar fertilizer based on cobalt and molybdenum $(\mathrm{Fcm})$

- - -Manganese phosphite (FMn)

-. - FMn+Fmm

$-\cdots \mathrm{Fcm}+\mathrm{Fmm}$

$--\mathrm{FMn}+\mathrm{Fcm}+\mathrm{Fmm}$

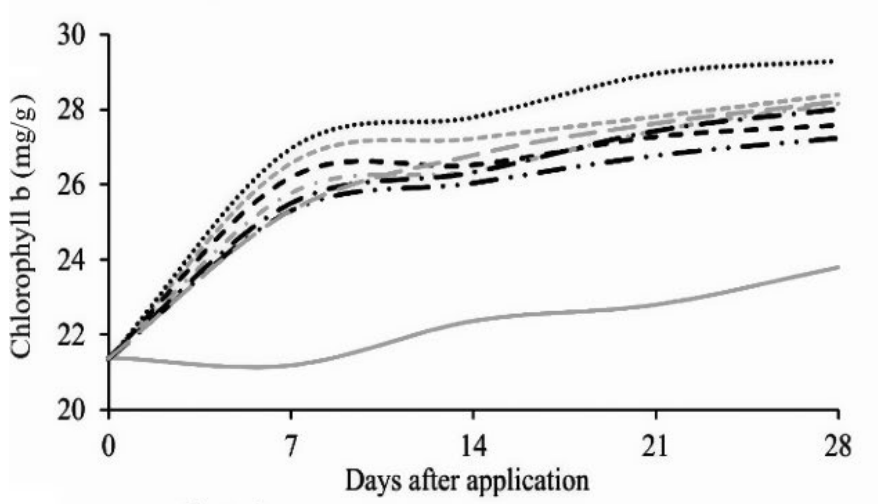

(c) Control

.......... Foliar fertilizer based on macro - and micronutrients $(\mathrm{Fmm})$

- - Foliar fertilizer based on cobalt and molybdenum ( $\mathrm{Fcm}$ )

- - -Manganese phosphite (FMn)

-. - FMn+Fmm

$--\mathrm{Fcm}+\mathrm{Fmm}$

$-\cdots \mathrm{FMn}+\mathrm{Fcm}+\mathrm{Fmm}$

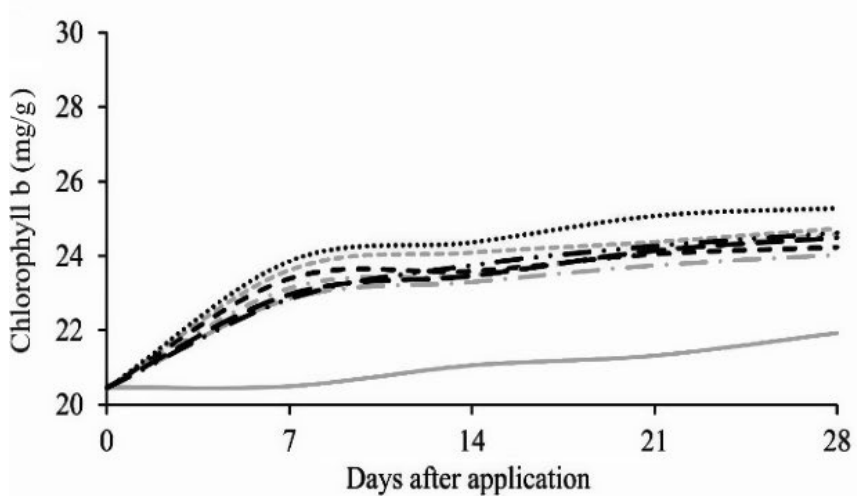

(b) AUACPC - - -Increase

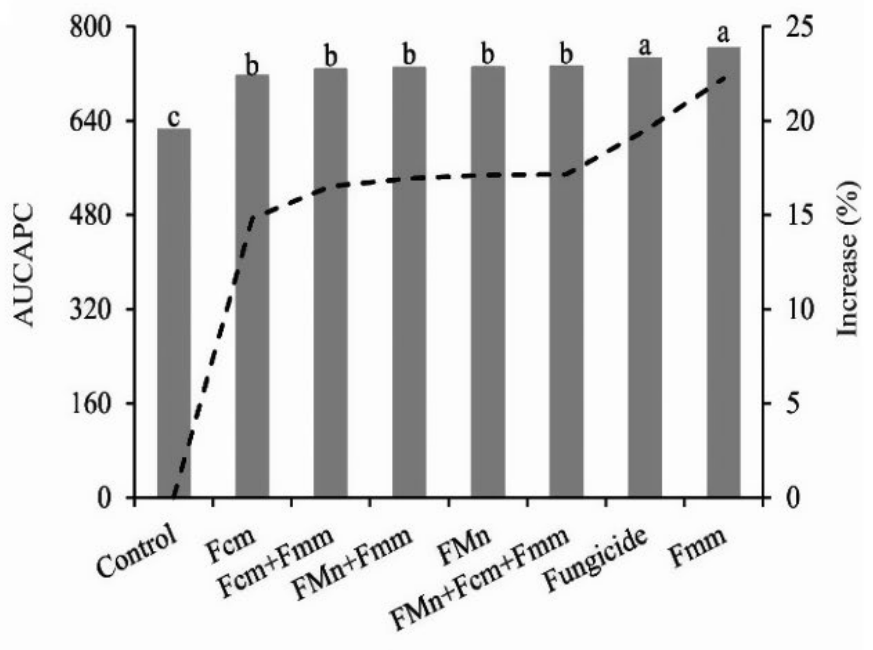

Treatments

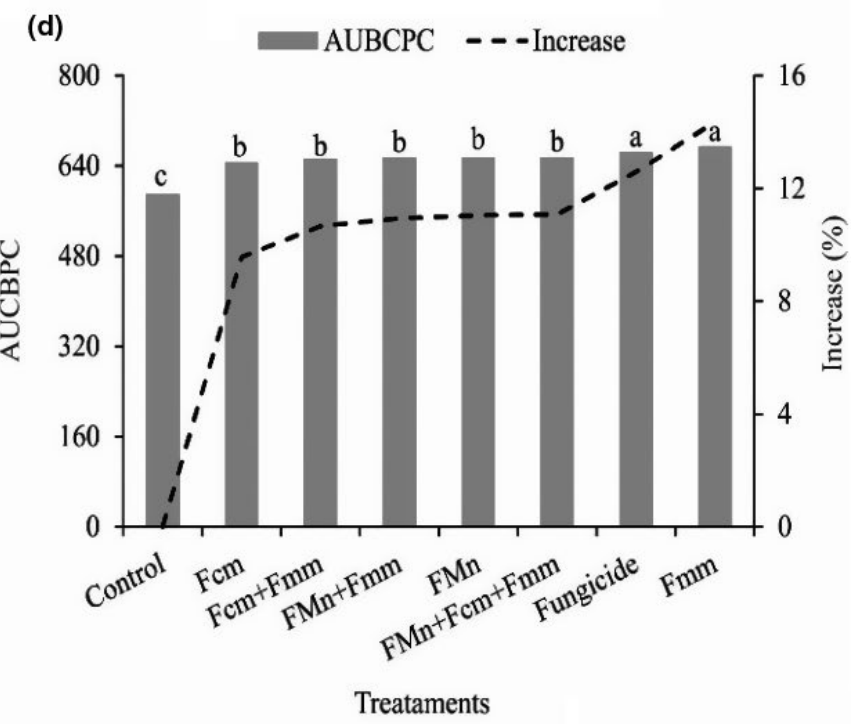

FIGURE 2 Effect of treatments on the production of chlorophyll a (A) and b (B), the area under the progress curve of chlorophyll a (AUACPC) (C) and chlorophyll B (AUBCPC) (D) content and their respective increases in comparison with the controls. Bars with same letter do not differ according to the Scott-Knott test $(p \leq 0.05)$

\section{4 | DISCUSSION}

Foliar fertilization is an essential practice for cultivating coffee trees, and its effects may go beyond nutrition. As the nutrients in the formulations of commercial fertilizers may be cofactors of enzymes related to plant defence against pathogens, the spraying of such products may interfere disease intensity. Treatments had the highest disease control as well as the lowest AUSPC in comparison with the control. Such compounds are present in high concentrations in coffee tree tissues, and they are also bioactive and able to trigger the plant defence against biotic stresses mostly when they are oxidized to quinones, which are compounds with an even higher toxicity (Santos et al., 2007). Costa et al. (2014) also observed a $72 \%$ and $58 \%$ reduction in the brown eye spot and rust intensity, respectively, in coffee trees following the spraying of manganese phosphite; however, they did not study its effects on net photosynthesis.

In this study, the treatments that provided control of phoma leaf spots significantly increased the chlorophyll a and b contents, the liquid photosynthetic rate and the PAL activity. The increase of chlorophyll $a$ and $b$ and the photosynthetic rate increased the green leaf area and decreased the disease intensity because of the reduction of necrotic area in relation to the total area of the leaf. In addition, it provided more glucose, or energy, for cell processes, among them those involved in the defence mechanism, balancing the amounts to avoid the accumulation of carbohydrates in the cuticle and their subsequent use by pathogens.

The FMn is a formulation comprising phosphorus (P), as phosphite and manganese (Mn). According to Dalio et al. (2012), this 
FIGURE 3 Effect of treatments on the liquid photosynthetic rate (LPR) and their increases in comparison to the control. Means with the same letters do not differ according to the Scott-Knott test $(p \leq 0.05)$

FIGURE 4 Effect of the treatments on the lignin content and on the increases provided by the treatments $(A)$ and the percentage activity of phenylalanine ammonia lyase (PAL) in relation to the control throughout assessments (B)
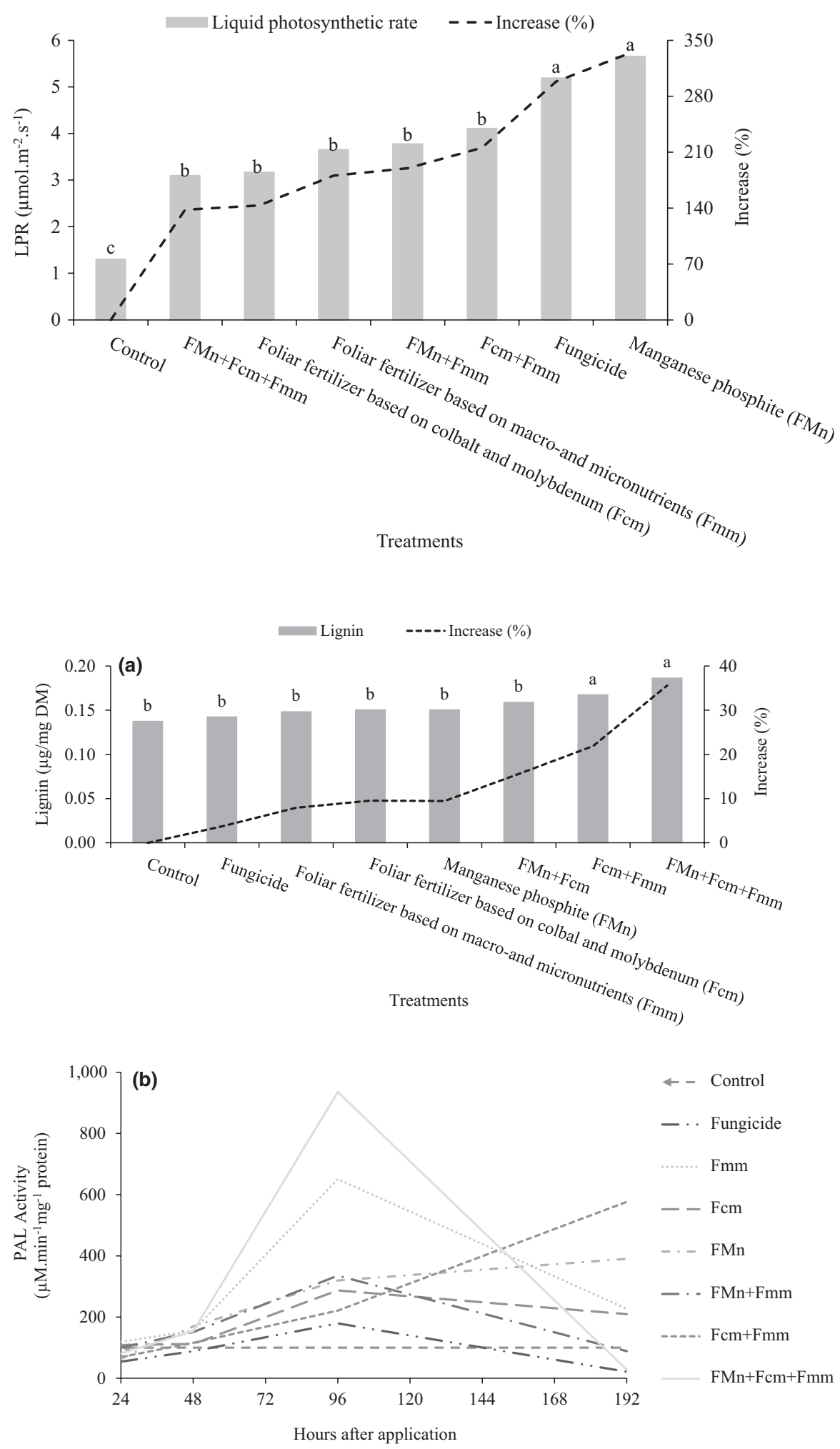

form of phosphorus is not metabolized by the plant as a nutrient; therefore, the increased photosynthetic rate provided by this foliar fertilizer is due to the manganese. Manganese $(\mathrm{Mn})$ is an essential element to the growth and development of plants and it is required in several metabolic processes, mostly in photosynthesis, which uses the light energy to oxidize water and oxygen in the reaction centre of photosystem II (PSII). Four manganese atoms present in this centre, along with one calcium atom, are responsible for the transfer of four electrons to photosystem I (PSI) (Gong et al., 2011; Taiz \& Zeiger, 2013); therefore, any increase or decrease in the supply of $M n$ to the plant may affect photosynthesis.

The higher concentration of chlorophyll $a$ and $b$ in coffee seedlings treated with Fmm was probably because Fmm has nitrogen in its formulation, which is a component of the chlorophyll molecule. 
According to Godoy, Santos, Villas Boas, and Leite Júnior (2008), there is a correlation between chlorophyll meter readings, chlorophyll content and the concentration of nitrogen in coffee leaves. Thus, according to Reis, Furlani Júnior, Buzetti, and Andreotti (2006), the increased dosages of nitrogen provided to plants promote higher SPAD reading values because of the increased chlorophyll contents.

The effect of the FMn+Fmm treatment on the PAL activity and lignin content is due to the manganese present in this mixture. According to Gong et al. (2011), manganese triggers approximately 35 enzymes involved in different processes, and among them, there is PAL-a key enzyme in the metabolism of phenolic compounds, catalysis and deamination of phenylalanine to cinnamic acid which, in turn, is a key substrate for the synthesis of lignin and phenolic compounds.

The cobalt and molybdenum ions present in Fcm are cofactors of enzymes and metabolic pathways for the synthesis of plant defence compounds (Graham \& Webb, 1991).

\section{5 | CONCLUSIONS}

Fcm and the FMn+Fmm mixture are, among the foliar fertilizers tested, the most effective treatments to reduce the severity of phoma leaf spot in coffee seedlings, increasing PAL activity. Fmm provided the highest increase in the chlorophyll $a$ and $b$ contents, and manganese phosphite (FMn) was the treatment that provided the highest net photosynthetic rate.

\section{ACKNOWLEDGEMENTS}

The authors would like to thank Stoller for the support to perform the study, to the Conselho Nacional de Desenvolvimento Científico e Tecnológico (CNPq) for the research fellowship, to the National Institute of Science and Technology of Coffee (INCT-Café) and to the Foundation for Research Support of Minas Gerais (FAPEMIG) for supporting the work.

\section{ORCID}

Bruno H. G. Costa iD http://orcid.org/0000-0003-3709-0735

Deila Magna dos Santos Botelho iD http://orcid.

org/0000-0002-3047-0164

\section{REFERENCES}

Aktar, M. W., Sengupta, D., \& Chowdhury, A. (2009). Impact of pesticides use in agriculture: their benefits and hazards. Interdisciplinary Toxicology, 2(1), 1-12. https://doi.org/10.2478/v10102-009-0001-7

Arnon, D. I. (1949). Copper enzymes in isolated chloroplasts: Polyphenoloxidase in Beta vulgaris. Plant Physiology, 24, 1-15. https:// doi.org/10.1104/pp.24.1.1

Bradford, M. M. (1976). A rapid and sensitive method for the quantitation of microgram quantities of protein utilizing the principle of protein-dye binding. Analytical Biochemistry, 72, 248-254. https:// doi.org/10.1016/0003-2697(76)90527-3
Costa, B. H. G., Resende, M. L. V., Monteiro, A. C. A., Ribeiro Júnior, P. M., Botelho, D. M. S., \& Silva, B. M. (2017). Potassium phosphites in the protection of common bean plants against anthracnose and biochemical defence responses. Journal of Phytopathology, 166(2), 95-102. https://doi.org/10.1111/jph.12665

Costa, B. H. G., Resende, M. L. V., Ribeiro Júnior, P. M., Mathioni, S. M., Pádua, M. A., \& Silva Júnior, M. B. (2014). Suppression of rust and brown eye spot diseases on coffee by phosphites and by-products of coffee and citrus industries. Journal of Phytopathology, 162, 635-642. https://doi.org/10.1111/jph.12237

Dalio, R. J. D., Ribeiro Júnior, P. M., Resende, M. L. V., Silva, A. C., Blumer, S., Pereira, V. F., ... Pascholati, S. F. (2012). O triplo modo de ação dos fosfitos. Revisão Anual de Patologia de Plantas. In: Wilmar C. Luz. (Org.). Revisão Anual de Patologia de Plantas. 1 ed. Passo Fundo: Revisão Anual de Patologia de Plantas - RAPP. 20, 206-242.

Gadaga, S. J. C., Abreu, M. S., Resende, M. L. V., \& Ribeiro Júnior, P. M. (2017). Phosphites for the control of anthracnose in common bean. Pesquisa Agropecuária Brasileira, 52(1), 36-44. https://doi. org/10.1590/S0100-204X2017000100005

Godoy, L. J. G., Santos, T. S., Villas Boas, R. L., \& Leite Júnior, J. B. (2008). Índice relativo de clorofila e o estado nutricional em nitrogênio durante o ciclo do cafeeiro fertirrigado. Revista Brasileira de Ciência do Solo, 32, 217-226. https://doi.org/10.1590/S0100-06832008000100021

Gong, X., Hong, M., Wang, Y., Zhou, M., Cai, J., Liu, C., ... Hong, F. (2011). Cerium relieves the inhibition of photosynthesis of maize caused by manganese deficiency. Biological Trace Element Research, 141(1-3), 305-316. https://doi.org/10.1007/s12011-010-8716-z

Graham, R. D., \& Webb, M. J. (1991). Micronutrients and disease resistance and tolerance in plants. In J. J. Mortvedt, F. R. Cox, L. M. Shuman, \& R. M. Welch (Eds.), Micronutrients in agriculture, 2nd ed. (pp. 329-370) (1). Madison, Wisconsin: Soil Science Society of America.

Huber, D.M. (1980). The role of mineral nutrition in defense. In J.G. Horsfall \& E.B. Cowling (Eds), Plant pathology: An advanced treatise, 5 (pp. 381-406). New York, NY: Academic.

Lichston, J. E., \& Godoy, S. A. P. (2006). Morfologia e teor de cera de folhas de café após aplicação de fungicida. Pesquisa Agropecuária Brasileira, 41(6), 919-926. https://doi.org/10.1590/ S0100-204X2006000600004

Lima, L. M., Pozza, E. A., Torres, H. N., Pozza, A. A. A., Salgado, M., \& Pfenning, L. H. (2010). Relação nitrogênio/potássio com mancha de Phoma e nutrição de mudas de cafeeiro em solução nutritiva. Tropical Plant Pathology, 35(4), 223-228. https://doi.org/10.1590/ S1982-56762010000400003

Nojosa, G. B. A., Resende, M. L. V., Barguil, B. M., Moraes, S. R. G., \& Vilas Boas, C. H. (2009). Efeito de indutores de resistência em cafeeiro contra a mancha de Phoma. Summa Phytopathologica, 35(1), 60-62. https://doi.org/10.1590/S0100-54052009000100011

Pozza, E. A., \& \& Pozza, A. A. A. (2012). Relação entre nutrição e as doenças de plantas: Implicações práticas. In: A. K. F. M. Machado, C. Ogoshi, F. J. Perina, G. M. Silva, H. S. Neto, L. S. A. S. Costa, N. E. Alencar, S. J. Martins, W.C. Terra \& W. L. A. Zancan (Eds.), Avanços na otimização do uso de defensivos agrícolas no manejo fitossanitário, 1 (pp. 259-282). 1 ed. São Carlos - SP: Suprema Gráfica e Editora.

Pozza, E. A., Carvalho, V. L., \& Chalfoun, S. M. (2010). Sintomas e injúrias causadas por doenças em cafeeiro. In R. J. Guimarães, A. N. G. Mendes, \& D. P. Baliza (Eds.), Semiologia do cafeeiro: Sintomas de desordens nutricionais, fitossanitárias e fisiológicas (pp. 68-106). Lavras, Brazil: UFLA p.

Pozza, E.A., \& Pozza, A.A.A. (2012). A Nutrição Mineral no Manejo de Doenças de Plantas. In: Grupo de Estudos Avançados em Fitopatologia (Ed.), Nutrição no manejo de doenças de plantas (pp. 177-212). Viçosa, Brazil: GEAFIP.

Reis, A. R., Furlani Júnior, E., Buzetti, S., \& Andreotti, M. (2006). Diagnóstico da exigência do cafeeiro em nitrogênio pela utilização 
do medidor portátil de clorofila. Bragantia, 85, 163-171. https://doi. org/10.1590/S0006-87052006000100021

Rodrigues, F. A., Jurick, W. M., Danoff, L. E., Jones, J. B., \& Rollins, J. (2005). Silicon influences cytological and molecular events in compatible and incompatible rice-Magnaporthe grisea interactions. Physiological and Molecular Plant Pathology, 66, 144-159. https://doi. org/10.1016/j.pmpp.2005.06.002

Salgado, M., Pozza, E. A., Lima, L. M., Pereira, R. T. G., \& Pfenning, L. H. (2009). Escala diagramática para avaliação da severidade da Mancha de Phoma do cafeeiro. Tropical Plant Pathology, 34, 422-427. https:// doi.org/10.1590/S1982-56762009000600010

Santos, L. S. D., Pozza, E. A., Faria, M. A., Silva, M. L. O., Custódio, A. A. P., Vasco, G. B., \& Castro, B. M. M. (2014). Incidência da mancha de Phoma em cafeeiro irrigado por gotejamento, sob diferentes manejos de irrigação. Coffee Science, 9, 77-89.

Santos, F. S., Souza, P. E., Resende, M. L. V., Pozza, E. A., Miranda, J. C., Ribeiro Júnior, P. M., \& Manerba, F. C. (2007). Efeito de extratos vegetais no progresso de doenças foliares do cafeeiro orgânico. Fitopatologia Brasileira, 32, 59-63. https://doi.org/10.1590/ S0100-41582007000100009

Shaner, G., \& Finney, R. E. (1977). The effect of nitrogen fertilization on the expression of slow-mildewing resistance in knox wheat. Phytopathology, 67, 1051-1056. https://doi.org/10.1094/ Phyto-67-1051

Silva, A. C., Souza, P. E., Resende, M. V. L., Silva Júnior, M. B., Ribeiro Júnior, P. M., \& Zeviani, W. M. (2014). Local and systemic control of powdery mildew in eucalyptus using essential oils and decoctions from traditional Brazilian medicinal plants. Forest Pathology, 44, 145153. https://doi.org/10.1111/efp.12079/epdf

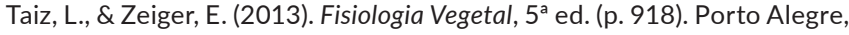
Brazil: Artmed.

Whitham, F. H., Blaydes, D. F., \& Devlin, R. M. (1971). Experiments in plant physiology (p. 58). New York, NY: D. V. Nostrand.

Zucher, M. (1965). Induction of phenylalanine deaminase by light and its relation to chlorogenic acid synthesis in potato tuber tissue. Plant Physiology, 40, 779-784. https://doi.org/10.1104/pp.40.5.779

How to cite this article: Silva Júnior MBD, Pozza EA,

Resende MLV, et al. Foliar fertilizers for the management of phoma leaf spot on coffee seedlings. J Phytopathol. 2018;166:686-693. https://doi.org/10.1111/jph.12745 